\title{
COLLECTIVE ACTS AS DISTINGUISHED FROM CONTRACTS ${ }^{1}$
}

\author{
LÉON DUGUIT \\ Professor of Public Law, University of Bordeaux
}

I

NATURE OF THE QUESTION

For a long time it has been a dogma admitted by the jurists of all countries that a contract alone could create consensual legal relations between individuals, in the absence of an express provision of the law assimilating, by way of exception, a unilateral act to a contract. On the other hand, it has been admitted with equal unanimity that whenever several concurrent declarations of will occur, a contract exists If the unilateral act produces legal effects in the domain of public law the reason was said to be that it emanates from a person invested with public power; but even in the matter of public law, when the public power does not appear in the foreground, a contract alone can create consensual legal relations; and in this field also there is a contract whenever there is a concurrence of will.

In the course of the last twenty-five years a double evolution has taken place in ideas and facts; the facts have acted on the ideas and the ideas on the facts. The question has been asked what was the value in law of this notion of public power which, under the persisting influence of Roman conceptions, has for centuries been declared to be an indispensable and intangible postulate. It was recognized that this notion was neither more indispensable nor more intangible than many others which had long been so considered. It was further recognized that in order to understand how a unilateral act emanating from governments or their agents can produce legal effects, it is useless to admit the postulate of public power, and that its creative force is not explained through the hypothesis of an imperium, but solely through the conformity of the act to the objective law of the social group in which it occurs. If a unilateral declaration of will which conforms to the objective law may of itself produce a legal effect in the domain of public law, there is no reason why the same should not be true in the domain of private law.

We have thus been led to inquire whether there are not in private law many acts, hitherto considered as contractual, which in reality are

${ }^{1}$ Translated from the French by Ernest G. Lorenzen, Professor of Law in Yale University.

$5 \mathbf{I}$ 
only unilateral acts, and to which in consequence the ordinary law of contracts should not be applied.

On the other hand, numerous cases have appeared in the domain of public law, internal as well as international, where there is a concurrence of wills and where nevertheless one has a distinct feeling that there is no contract. For example, in countries in which legislation proceeds from the concurrence of the wills of two chambers or of such chambers and a chief magistrate, it cannot be said that there is a contract between the chambers or between the parliament and the chief magistrate. It is likewise clearly seen that the official acts of a corporate agency are not per se contracts. Finally, in certain acts based perhaps upon agreement, such as the appointment of a public officer, or the granting of a franchise for a public service, one may see this less clearly, but the impression certainly is that it would be taking a false view to see therein contracts of the classical and professional type.

The observations made in the domain of public law have led naturally to the inquiry whether in private law also there were not many cases in which there exists a concurrence of wills, and in which nevertheless it cannot be said that there is a contract in the traditional and civilian sense of the word. We were forced to recognize that such was the case. But the habit was so strong, the tradition had become so deeply encrusted in our minds, that it was impossible for a while-at least in France-to discard the notion of a contract. We desired to maintain the thing and the word, but we added to the word epithets which, although we did not see it, were inconsistent with it. We spoke of contracts of adhesion, of collective contracts-expressions which contain a contradiction in adjecto.

Facts and ideas progress, however, notwithștanding the opposition of jurists adhering to tradition, and the time has come for us to recognize that in the domain of private law as in that of public law there is a series of cases in which, although there is a concurrence of wills, it cannot be said that there is a contract. It does not suffice, however, for us to arrive at a negative conclusion. We must find a positive solution. The thing is not easy. The difficulties have arisen from the fact that we have tried to put into a single category all the cases in which there is a concurrence of wills without the existence of a contract.

If we proceed to a more thorough analysis we perceive that a distinction must be made between the cases in which the concurrence of wills is only the sum total of unilateral declarations of wills, and those in which the legal relation is created by the unilateral will of the parties. In this case alone the expression collective act (in German, Gesammtakt), the word designating a plurality of unilateral acts, should be used.

In certain cases, on the other hand, there is clearly a concurrence of 
wills, a bilateral act, an agreement, if you like; but there is no contract. We have here a juridical act of a specific nature which is neither a contract nor a unilateral act. Jellinek and Triepel have given it the name of Vereinbarung, of which the French and English word "union" is the literal translation and which I propose to accept.

It is not my intention to study and to analyze all the instances in public and private law in which the collective act or union appears. That would far exceed the dimensions of an article for this JourNAL. I shall content myself with studying the collective act and the union in the domain of private law, taking two characteristic examples-the formation of associations and the collective labor agreement. ${ }^{2}$

\section{II}

THE TRADITIONAL NOTION OF A CONTRACT

The principal point is to determine exactly what a contract is. Notwithstanding the controversies which exist on the point, the thing is not very difficult. We must not forget that the contract is a creation of the Roman law which accords with a juridical system that is essentially subjective and individualistic. The Roman conception of a contract is materalized in the form of a stipulatio, a mold into which every contract could be put.

Gaius has told us: "Verbis obligatio contrahitur ex interrogatione et responsu, cum quid dari fierive nobis stipulamur."3 Verbis obligatio fit ex interrogatione et responsione velut: Dari spondes? Spondeo.

\footnotetext{
${ }^{2}$ For twenty-five years the question has given rise to an extensive literature in Germany and in Italy. I regret to say that the same is not true in France. I believe the great German jurist Gierke was the first to show that it was a complete mistake to see a contract in the constitutive act of an association or corporation-Gierke, Die Genossenschaftstheorie (1887) 133. Jellinek has shown that there are many cases in public law in which there is a concurrence of wills without the existence of a contract. He considers that there is in this case a juridical act possessing a specific characteristic which distinguishes it from the unilateral act and the contractual act, a juridical act which he calls Vereinbarung.-Jellinek, System der öffentlichen subjektiven Rechte (1892) I93, I94. In 1899, Triepel developed and made more specific this distinction between contract and Vereinbarung. He saw in Vereinbarung the basis of objective international law.-Triepel, Völkerrecht und Länderrecht (1899). A complete bibliography will be found in the thesis of Gleitsmann, Vereinbarung und Gesammtakt (Halle, rgoo).

The question has been much studied in Italy, especially by Borsi, L'atto amministrativo complesso, in 20 Studi senesi (Ig02); Donato-Donati, Atto complesso, in I2 Archivio juridico (Ig03).

In France the question has been studied but little. See, however, Bézin, Exposé des doctrines allemandes et italiennes sur lacte complexe, in Recueil de législation de Toulouse (I905) 289; Hauriou, Principes de droit public (2d ed I9I6) I36 et seq.

Digest XLI, 7, I, § 7; Institutes III, I5.
} 
This form shows clearly two wills which are manifested outwardlytwo declarations of will, to use the modern expression, two wills which have come into contact. There are two individuals who knowingly agree and bind themselves, one stating that he stipulates, that is, that he wills to become a creditor, the other stating that he promises, that is, that he wills to become a debtor. ${ }^{*}$ The one who wills to become creditor does so because he thinks that the other wills to become debtor; the other who wills to become debtor does so because he knows that the other wills to become creditor. The two wills concur but each has its own objects and aims.

Thus there is formed a legal tie between two persons whose situation and interests are opposed: one is bound to effect a certain "prestation" or "performance"s with respect to the other, who in turn has the power to demand that performance.

A juridical act is a contract only if it can enter into the mold of such a contract as the stipulatio. I want to say that a contract exists only if the clauses of a juridical act, however complex we may assume them to be, may enter into the framework of one or more stipulationes. If they do not, something other than a contract exists: it may be an agreement, but it is not a contract.

This Roman conception of a contract has been transmitted to the modern law through the agency of the great Romanists of the Middle Ages and of the Renaissance, by the great French jurists of the seventeenth and eighteenth centuries, and especially by Pothier. It is to-day expressed in all the codes of Europe and America.

Pothier defined a contract as an agreement by which the two parties reciprocally (or only one of them) promise and bind themselves with respect to the other to give him something. Virtually the same definition may be found in the Code Napoléon: "A contract is an agreement by which one or several persons bind themselves with respect to another or several others to give, to do, or not to do a certain thing." The German Civil Code does not give a definition, properly so called, of a contract (Vertrag). But it clearly appears from different articles that it has maintained intact the traditional Roman notion of a contract. It should be noted in the first place that the German Code uses the word Vertrag only when the question concerns the creation, extinction, or assignment of an obligation. When the question concerns the

\footnotetext{
" "By the term 'creditors' is meant not only those who have loaned money, but all to whom something is owing for any reason." Digest of Justinian, L. I6, Ir. Similarly in modern continental law the party obligated is called debtor and the party entitled to a "performance" is called creditor.-[Translator.]

"Prestation-in German, Leistung-is the general term describing an act or forbearance which one person is entitled to claim from the other by reason of an obligatory relation existing between them. Schuster translates the term by the word "performance:" The Principles of German Civil Law, 137.-[Translator.]

- Art. rior.
} 
creation or assignment of a right in a res it uses the word Einigung. The German Civil Code says:" "A contract is concluded by the acceptance of an offer ..." And in another place: "For the creation of an obligation by juristic act, and for any alteration of the substance of an obligation, a contract between the parties is necessary, unless it is otherwise provided by law." Thus a contract exists only when an offer has been accepted with the object of creating an obligatory relationship-that is, a relationship of creditor and debtor between the offeror and the acceptor.

The same conception is clearly formulated in the codes of the New World. I shall refer to only three by way of example. The Civil Code of the Argentine Republic, drafted between I868 and I870 by the eminent Argentine jurist Dalmacio Velez-Sassfield, contains a clear expression of the traditional notion of a contract. It is placed under the title: Obligations which Arise out of Contracts. The characteristic of a contract is thus the creation of an obligation between the contracting parties. The agreement is formed by the offer of one of the parties and its acceptance by the other. ${ }^{-}$In the Civil Code of Louisiana there is a definition of contract copied from that of the Code Napoléon:10 "A contract is an agreement, by which one person obligates himself to another, to give, to do or permit, or not to do something, expressed or implied by such agreement." An almost identical definition is found in the Civil Code of Georgia :11 "A contract is an agreement between two or more parties for the doing or not doing of some specified thing."

Such is the notion of a contract which is unanimously admitted by the civilians of all countries. It would serve no good object to reproduce the different definitions given, all of which turn on the same point, and I shall content myself with citing a passage borrowed from the classical work of Aubry and Rau, the reputation of which is universal:12 "An agreement is the accord between two or more persons with respect to an object of juridical interest. The agreement which has for its object the formation of an obligation is called more particularly a contract. The agreement is the genus; the contract, the species."

A contract is therefore a juridical act whose specific character is clearly determined. It is created by the declarations of will proceeding from two individuals or two groups of individuals and implying a preliminary accord. Each of these declarations of will has an object of its own; each has an aim of its own because it is determined by the

\footnotetext{
${ }^{2}$ Art. 151.

${ }^{8}$ Art. 305.

- Argentine Civil Code, arts. II7I, II72, II78.

${ }^{10}$ Art. I76r.

11 (Adopted Aug. I5, 1910) art. 4216.

${ }^{12}{ }_{4}$ Cours de droit civil français, 283.
} 
other. The act as a whole has for its object the creation of a situation uniting two persons or two groups of persons between whom exists the relation of creditor and debtor. ${ }^{13}$ In the situation which arises from a contract there are always two persons and only two personsor two groups of persons. All the persons of the same group are in the same situation with respect to those of the other group, and each person or each group of persons is in a different situation and has opposing interests, one being creditor, the other being debtor, each having so willed.

Finally, a contract is an accord entered into between two persons having for their object the creation of an obligation at the expense of one-the debtor, and for the benefit of the other-the creditor.

The notion of obligation and that of contract are thus intimately related. An obligation may arise otherwise than from a contract. A contract is the cause and the obligation the effect. But it is none the less true that an act which does not have for its object the creation of an obligation is not a contract. For this reason the Code Napoléon and other codes include under the title of Contracts or Obligations Arising from Agreement in General, dispositions relating to obligations and to contracts. This is certainly a bad method, but the explanation is historical and discloses the intimate relation existing between the notions of contract and obligation.

The above being established, it follows that there may be a concurrence of wills without there being a contract; that no contract exists when there are several declarations of wills which have the same object; that there is no contract, although there is an agreement, whenever the object of the parties is the creation of a situation which does not constitute a relationship of creditor and debtor.

What have we then when there is no contract? I shall try to show this. But it matters little: the principal thing is to assert that there is no contract and that the application of the ordinary law of contracts in such a case would involve a false view which would lead to grave mistakes.

\section{III}

PLURALITY OF UNILATERAL DECLARATIONS OF WILL-THE ASSOCIATION

Practical modern needs and the great development of commerce and industry have given rise to juridical formations which are called corporations (sociétés anonymes) and associations. They have essentially the same characteristics: the uniting of capital and labor for the attainment of a certain end, which we assume to be lawful, in conformity to a rule accepted by the members and constituting what are called the articles of association.

${ }^{23}$ See note 4 , supra. 
French law, in consequence of historical circumstances which we need not here explain, distinguishes clearly between corporations and associations according to a criterion which is in reality a purely formal one. A corporation is a uniting of capital and labor for the attainment of a purpose lucrative to its members. An association is the union of capital and labor for the attainment of a non-lucrative purpose for the benefit of its members or for the benefit of persons who are not members of the association. ${ }^{14}$

I shall take as an example the association as just defined. The French legislator who has neglected to make even a superficial analysis of this act has seen therein a contract and has stated in the aforesaid text that the association should be governed by the general principles of law applicable to contracts and obligations. This is clearly an error which will lead to regrettable consequences. In order to show this we must distinguish between the preparatory period and the formation, properly so called, of the association.

During the preparatory period those who promote the association agree upon the manner in which it shall be created, on the contributions of each of them and upon the role which each is to play in the association. That true contracts are thus made cannot be doubted. There are agreements, accords between persons who intend to bind themselves one to another.

These agreements may also contain stipulations for the benefit of others which are valid as the condition of a contract which the parties have made on their own behalf, and which have such force as the laws of most countries attribute to them, such laws differing somewhat in detail.

The above are contracts according to the traditional conception and they have the traditional force. But none of these acts, however definite and developed we may assume it to be, constitutes an association. So long as there are only these acts there is no association as yet, and even the effects of these acts are subordinate to the suspensive or resolutory condition, according to the intention of the parties, that the association shall be formed. The formation of the association is therefore distinct from such acts and is an entirely different thing.

When the above understanding has been reached the promotors of the association make an appeal to the public. On the day and at the hour announced the persons responding to the appeal assemble. The promotors have drawn up articles of association-rules and provisions of a general nature which contain five things: First, the object of the association; second, its name; third, its home office; fourth, the composition of the organization which is to administer its affairs; and fifth, nearly always, the amount of the annual contributions which are to be paid by the members. These propositions are discussed at the

"French Law of July I, Igor, art. I. 
meeting; the proposed rules are then adopted and the articles are approved.

The association is thus formed and it includes as members all those who have approved the articles. That is the constitutive act.

That there is a concurrence of wills is unquestionable; that there is a plurality of declarations of concurring wills, there is no doubt. But certainly there is no contract.

In the first place, there has been no contact between the different wills that approved the articles of association. One of them has not made an offer to another which has been accepted. The different persons who were found in the hall did not in reality enter into relations one with another. They have not exchanged promises with the object of creating between themselves an obligation, a relationship of creditor and debtor. One of them has not willed to bind himself, influenced by the will of the other to become creditor, and vice versa. On the contrary, all these persons intended the same thing: the formation of an association according to the articles which they have approved. All these declarations of will have been determined by the same end, namely, the one which the articles that have been approved give to the association.

After the association is formed, does there exist an individual relationship of creditor and debtor between its members? Not at all. There is a permanent situation, regulated by the articles of association, which are really a law for the group-a law which applies not only to the members, not only to the agencies of the association, but also to third parties who enter into relations with these agencies.

The articles are the permanent law governing the members so long as they remain in the association. They impose obligations, the most usual of which is that of paying an annual contribution. A member may be regarded in this respect as the debtor of the association, which in turn is his creditor. But if the relation of creditor and debtor exists between the association and its members, it by no means arises from a contract between the members of the association, which is anterior to the approval of the articles, since the association did not exist at that time. Moreover, if the member is a debtor of the association, he has become debtor by virtue of law. $\mathrm{He}$ is in a situation analogous to that of a taxpayer, the amount of whose debt may be increased by law in spite of himself. The amount of the contribution may be increased by the majority in conformity to the articles, and the dissenting members will have to submit to this act of the majority just as the taxpayer must submit to an increase of taxes determined by the law. This could not be so if there was a contract.

The articles apply to the members, who may be placed under what is really a penal law-a disciplinary law. They may actually inflict punishments and establish an agency of the association which, like a real court, shall pronounce them. The member can do nothing which 
constitutes a direct or an indirect injury to the aims of the association, which interferes with its activity, or stains its reputation. Every act of this kind constitutes a disciplinary infraction which the articles may provide against and punish by a fine or by exclusion from the association. The last constitutes the gravest punishment that can be inflicted. There are numerous associations in which this is done. We have thus a penal or disciplinary régime which leads us far away from a contract; a well-defined juridical act which creates a relationship of creditor and debtor between two juristic subjects.

The articles also apply to third parties. All dealings with third parties in the name of the association are governed by the articles, which may be invoked by those parties just as they may be invoked against them. These articles determine the capacity and the powers of the agencies of the association, and if the latter have done acts beyond their authority, the nullity of those acts may be invoked by the third parties just as it may be invoked against them.

The articles of association determine its object. Its agencies can act only in conformity with its object; every act done in violation of this object is null and void. Moreover, this nullity, which has as its basis the articles of association, may be invoked against third parties as well as by them.

May we say that the validity of a contract with third parties may be determined by another contract? This would be absolutely contradictory to the notion of a contract itself : a contract can change the legal relations only of the contracting parties. On the contrary, everything is explained and becomes luminously clear if we understand that the approval of the articles has been equivalent to the voluntary establishment of a law which is to govern the life of a new group.

Thus there arises the question indicated at the beginning of this article. Does this concurrence of wills which forms the association constitute a juridical act of a specific nature which distinguishes it at the same time from a contractual act and from a unilateral act? Is it a Vereinbarung - a union? I do not think so and I believe that there is simply a plurality of unilateral declarations of will, a plurality of unilateral acts; the validity of those acts is recognized by law because they are aimed at a lawful object. This results from the analysis which precedes.

Because of the celebrity of its author, I cannot pass by in silence Gierke's view according to which the constitutive act of an association has a specific character which distinguishes it from a contract and from a unilateral act. Gierke teaches that the constitutive act of an association is not simply a plurality of unilateral declarations of wills, because these wills do not remain isolated without contact among themselves, but on the contrary they all contribute to a common end and become fused in a common life. There is no contract because a contract contrasts two opposite wills-two wills which are bound by an agreement 
but which preserve their autonomy and play opposite roles in the situation which arises from the contract. In the present case, however, the wills are associated and are by no means opposed one to the other; they co-operate toward the same object; they tend to be merged and to be lost in a single new will which is the will of the association that has been formed.

"The act whereby the group is formed," writes Gierke, "is not a contract but a unilateral collective act which has no parallel in the law pertaining to the individual. The word contract of association is as inexact as regards the formation of a group as it is for the organization of a state or of a church and it can be accepted no more in private law than in public law. It is the will of the collective being in the process of formation which is developing and taking on form in order to assert itself in the constitutive act. In consequence the development of an association from its conception to its complete formation must be considered as one act. The innumerable individual acts which take place are comprehended as non-autonomous elements in the collective act, set in motion by a single centre. In consequence this collective act is already corporate action."15

It is impossible for me to follow the German jurist upon this ground. This is not the place to discuss the celebrated question of the juridical personality of collective bodies, a theory of which the Berlin professor has made himself the apostle. It must suffice to say that this conception of a purely metaphysical nature must in my opinion be rejected from every truly scientific theory of the law. It is the persistence of the scholastic concepts of substance and entities which are without value and of which jurisprudence should be rid once for all.

Gierke's negative proposition, "The act whereby the group is formed is not a contract," is fully established. I believe I have proved it. But we must not go further. A jurist should affirm nothing beyond what he finds in reality. In the present case we see as a matter of fact a certain number of individuals who approve articles because they desire to pursue in common a lawful object in conformity to those articles. It is neither a contract nor a Vereinbarung. There are several unilateral declarations of will which create objective law for a group pursuing an object recognized as lawful by the law of a given country.

IV

THE COLLECTIVE LABOR CONTRACT

The term "collective labor contract" has been used to describe the arrangements that have been brought about by the necessity of finding a solution for the conflicts which have arisen in all countries between

${ }^{15}$ Gierke, Die Genossenschaftstheorie (1887) 135 . 
labor and capital. The expression is bad. The two words contract and collective are contradictory, and the act which is thus designated is neither a contract nor a labor contract. That there is a concurrence of wills is unquestionable. It must even be admitted that there is an agreement, a fact which distinguishes it from the case considered above. But it must be unquestionably denied that there is a contract.

We use the term collective labor contract to describe the arrangement commonly entered into between representatives of capital and labor in a certain trade for the purpose of preventing or putting an end to a strike; an arrangement regulating the conditions upon which workmen in the trade shall thereafter be hired-such conditions, for example, as the hours of labor and the scale of wages. In simpler terms: the collective labor contract is an agreement which determines the law according to which individual labor contracts in a given trade shall be concluded.

By way of example, we may consider the arrangement entered into on February 7 th, I9I3, between the employers' association of bakers of Bordeaux and the bakers' labor union, fixing the daily wages and the conditions upon which employees might be dismissed by their employers; or, to take another example, the arrangement entered into in Paris on October $4^{\text {th, }}$ I9I7, between the association of employers in the artificial flower and feather industry, and the corresponding labor union. This arrangement determined the conditions for the application of the English week, and compensation for the higher cost of living.

We cannot fail to see that these acts constitute an agreement. The representatives of the employers and those of the employees in the trade have entered into contact; an accord has taken place. But this agreement is not a contract. It is not a contract whether considered in itself or from the point of view of the situation which arises therefrom. In a contract each contracting party wills a different thing and aims at a different object. In the present case both parties will the same thing: the creation of a general, permanent rule, of a law which shall henceforth control the conditions of work in their trade. The parties have the same object in view, namely, to avoid a conflict or to resolve one which has arisen between the employers and employees of a particular trade and to establish the law for their future relations.

As to the situation which arises from the collective labor contract, is it possible to see therein upon any basis whatever a. relationship of creditor and debtor, an obligatory relationship between one person who is under a duty to render a certain performance and another who has the right to demand it? There is simply a general, permanent rule, a law according to which the individual contracts in the trade shall be made, each of the contracting parties having the power to rescind an agreement which may have been entered into contrary to the rule established by the collective contract.

The jurists adhering to tradition have indeed been obliged to 
recognize that the collective contract did not give rise to true obligations between the contracting groups, and that if obligations did arise they resulted from the duty of the employers and employees to conclude individual labor contracts in conformity with the general rules established by the collective act. But these jurists have been considerably embarrassed to explain how these obligations could arise.

At first they have tried to explain the matter as a stipulation for the benefit of others which is provided for by Article II2I of the Code Napoléon and in similar provisions of many other codes. It may be law fully stipulated in a contract that the debtor, in addition to what he promises to the other contracting party, shall render a certain performance for the benefit of a third party, and even for the benefit of a person who shall be determined subsequently by an act which is quite independent of the will of the contracting parties. But in order that there may be a stipulation for the benefit of another it is necessary that a promise for the benefit of a third party be made and consented to in fact. In the collective contract there is nothing of the kind. The contracting unions do not agree that one of them shall render a certain performance to a third party, whether determined or not. A general, permanent rule has been established by which the individual contracts in the trade shall be regulated between employees and employers, between workmen and capitalists. However much we may search, no trace of a contract for the benefit of another can be found.

They have been obliged to admit the foregoing facts. They have then wanted to bring in the idea of mandate. The learned members of the Société des études législatives proceeded thus in 1907, when they tried to draft a law on the subject of collective labor contracts. ${ }^{16}$ In this mandate, however, the mandataries are the union and the association; the mandants are the individuals who comprise the union and the association at the time the collective agreement is made. Under these conditions the terms of the agreement are binding neither upon the employees nor upon the employers who were not respectively members of the union and of the association at the time of the agreement, nor upon those who withdraw therefrom subsequently, because in so retiring, they revoke the supposed mandate which they have given to their organizations. One might as well say, then, that the collective contract is without effect because the employers who are members of the association may always hire workmen who are not members of the union upon conditions which seem best to them, and because the employers merely have to withdraw from the association in order to be able to make such contracts as they please. A collective contract thus understood is a nonentity.

${ }^{10}$ Bulletin de la société des études législatives, 1907, pp. 180, 505; Report of $\mathrm{M}$. Colson and discussion, ibid. p. 532 et seq.; ibid. rg08, p. 82 et seq. 
This leads us to the conclusion, that what is called a collective labor contract is a very specific juridical category which is neither a plurality of unilateral acts nor a contract in the proper sense of the word. There is a concurrence of wills; there is an agreement between two groups which preserve their autonomy. But there is no contract because the object and the aim of the declarations of will are the same for all parties. Their wills have not as their object the creation of a situation of creditor and debtor; the object is to establish a general, permanent rule according to which labor contracts in the trade are to be made. These wills are determined by the same aim-to regulate or to prevent a conflict between employers and employees.

The collective labor contract is an agreement or law regulating the relations of two social classes. It is by no means a contract giving rise to special, concrete and temporary obligations between two juristic subjects. It is a law establishing permanent relationships between two social groups, the legal rule according to which the individual contracts between members of these two groups are to be concluded. Just as the articles of association are the law for a group, in the same way the clauses of a collective contract are the law which governs the relations between two social groups.

On July 29, I9r3, the French Chamber of Deputies approved a bill on the subject of the collective contract which is based directly upon these ideas. The text wrongly retains the expression "contract," although the title of the law is "The collective labor agreement." In article I, section 2, it is correctly stated that this agreement "determines the conditions which individual labor contracts must satisfy." The bill stipulates that all members of the groups that are parties to the collective labor agreement or that subsequently assent thereto are bound by it, provided they have not resigned from the group within the space of a week. Each group that is a party to a collective labor agreement made for an indeterminate duration may at any moment denounce it. This is logical, inasmuch as a law should always be subject to modification-even a law by agreement. But the law permits each member of a group that is a party to a collective labor agreement, unless he has surrendered such privilege, to free himself from the obligations resulting from that agreement by withdrawing from the group of which he was a member at the time the agreement was entered into; and he cannot surrender for a period of more than five years this privilege of freeing himself from an agreement which is in operation.

The provisions of the law do not well agree with the general notion of a collective labor agreement. We see therein a persistence of the individualistic conception of a contract of which the legislator has not been able to free himself completely and which threatens, if the law is definitely approved in these terms, to compromise its effectiveness. On the other hand, it was evidently with some difficulty that the legislator could be made to admit that the members of contracting unions 
could not by withdrawing from the union always get rid of the law which the collective contract had created.

The truth is that although collective labor contracts have multiplied, especially since the war began, the time has not yet come for legislative action. We have here an institution which is still in the process of formation and is far from its complete development. The working classes have not yet acquired a definite juridical structure'; in each trade, such strong and widespread labor unions and employees' associations do not exist that they may be regarded as identical with the trade; the laborers and employers outside such unions and associations may not be considered as negligible quantities.

I believe that many of the European countries-and especially France -are tending.toward this social state. Far from being arrested by the war, the evolution has rather been accentuated and has become more distinct. The employers' associations have a well-established organization in many trades. The evolution has perhaps advanced less so far as the labor unions are concerned, but that does not prevent the effectiveness and the sanction of the collective labor contract. Its provisions have for their special object the protection of the workman so far as salary and the maximum of daily work are concerned. When the employers' association has accepted the provisions of a collective labor contract, if this association constitutes in fact the organized trade, the agreement really becomes the law of the trade, and every workman, even if not a member of the union, should be able to invoke the application of that law.

\section{CONCLUSTONS}

The analysis which I have just made of the collective labor contract may be made with respect to many acts of private and public law which are agreements but not contracts, which do not create a relationship of obligations at all, but form the conditions for the application of a law to certain persons, or establish a rule of law in the substantive sense. In private law marriage is an act of this kind. It is not a contract strictly speaking. It is an agreement which is the condition for the application to the husband and wife of the law concerning the status of married people. In public law the appointment of public officers is an act of the same kind. It is difficult to say that there is no agreement between the state which appoints and the officer who is appointed; but this agreement is not a contract. The relationship of creditor and debtor is not created between the state and the public officer. A juristic situation is created; and the appointment is the condition for the application to the public officer who is appointed of the law concerning the public office in question. 
The same juridical phenomenon appears in public law in the granting of a franchise for a public service. An understanding, an agreement, is made between the state or municipality and the grantee, and this understanding constitutes the law which governs the operation of the public service in question. We would be outside of the actual facts, we would arrive at consequences that are absolutely untenable, if we should see in the granting of a franchise for a public service a contract and apply the ordinary law thereto. The difficulties and controversies which have arisen in France during the war between cities and corporations which hold franchises for public services have for their cause in great measure this mistake in the point of view.

In international law many treaties have the same character. Their object is by no means the creation of reciprocal obligations between the contracting states, but the establishment of a law regulating international relations in a permanent manner-a law which is very fragile, it is true, as the terrible events which the world is witnessing is showing only too plainly. But a crime never proves that the criminal law does'not exist. The crimes of Germany do not prove that there are no laws founded upon international treaties or laws which are binding upon states.

At the beginning of this study I put the following questions: Are there cases where there is a concurrence of wills without a contract? In the cases where there is a concurrence of wills without a contract, is there a juridical act of a specific character which is neither a unilateral act nor a contractual act?

To the first question I answer: Yes, there are numerous acts where there is a concurrence of wills without a contract. The second question I answer by making a distinction. Frequently in connection with a concurrence of wills there is by no means a true juridical act; there is simply a plurality of unilateral declarations, a number of unilateral acts. We may call this concurrence of unilateral acts a collective act, a Gesammtakt according to the German expression. But it must be clearly understood that there are simply a number of unilateral acts, the sum total of which are the conditions for the creation of a certain legal situation and especially for the creation of a collective group and of the law which governs it.

In the other cases, on the contrary, the concurrence of wills does constitute an agreement, but the agreement is not a contract. There the concurrence of wills forms a specific juridical act which is neither a unilateral act nor a contractual act. It is what the Germans call Vereinbarung and which I propose to call union. A typical example is the collective labor agreement, as I have tried to show. Such an agreement really constitutes a law which regulates the relations of two or more groups. In other cases the act of union is the condition for the application of a general law to certain persons, as husband and 
wife, or public officers; or it constitutes the law governing the franchise for a public service; or it establishes a rule of international law. The application of the union in public law as well as in private law is therefore wide, and it is bound to grow with the general movement which I have elsewhere tried to put into relief, ${ }^{17}$ which has become accentuated during the war, and which develops the law governing modern associations more and more in a socialistic and objective manner.

${ }^{17}$ See my two works, Les transformations générales du droit privé depuis le code Napoléon (Paris, 1912) and Les transformations du droit public (Paris, I9r3). 